\title{
Trace Elements in Edible Flowers from Italy: Further Insights into Health Benefits and Risks to Consumers
}

\author{
Giuliana Drava ${ }^{1, *} \mathbb{B}$, Valeria Iobbi ${ }^{1}$, Rafaël Govaerts ${ }^{2}$, Vincenzo Minganti ${ }^{1}$, Andrea Copetta ${ }^{3}{ }^{(}$, \\ Barbara Ruffoni ${ }^{3}$ and Angela Bisio ${ }^{1}$ \\ 1 Dipartimento di Farmacia, Università degli Studi di Genova, Viale Cembrano 4, 16148 Genova, Italy; \\ valeria.iobbi@edu.unige.it (V.I.); minganti@difar.unige.it (V.M.); bisio@difar.unige.it (A.B.) \\ 2 Biodiversity Informatics and Spatial Analysis, Royal Botanic Gardens, Kew Jodrell Laboratory, Kew Road, \\ Richmond TW9 3DS, UK; R.Govaerts@kew.org \\ 3 CREA Centro di Ricerca Orticoltura e Florovivaismo, Corso Inglesi 508, 18038 Sanremo, IM, Italy; \\ andrea.copetta@crea.gov.it (A.C.); barbara.ruffoni@crea.gov.it (B.R.) \\ * Correspondence: drava@difar.unige.it; Tel.: +39-010-335-2112
}

Academic Editor: Gavino Sanna

Received: 19 May 2020; Accepted: 18 June 2020; Published: 23 June 2020

\begin{abstract}
The use of edible flowers in cooking dates back to ancient times, but recently it is gaining success among the consumers, increasingly attentive to healthy and sustainable foods of high quality, without neglecting taste, flavour, and visual appeal. The present study aims to deepen the knowledge regarding the mineral composition of edible flowers, an aspect not widely investigated in scientific literature. The concentrations of $\mathrm{Cd}, \mathrm{Co}, \mathrm{Cu}, \mathrm{Fe}, \mathrm{Mn}, \mathrm{Ni}, \mathrm{Pb}, \mathrm{Sr}, \mathrm{V}$, and $\mathrm{Zn}$ have been determined by Inductively Coupled Plasma Optical Emission Spectrometry (ICP OES) in flowers belonging to a wide variety of species. The study highlights that some floral species are characterized by significantly higher concentrations of certain trace elements, e.g., the flowers of Acmella oleracea for Mn, those of basil (Ocimum basilicum) and of pumpkins (Cucurbita moschata and C. pepo) for $\mathrm{Cu}$ and $\mathrm{Sr}$, and those of orange daylily (Hemerocallis fulva) for Ni. Potentially toxic elements are present at low concentrations, often below the limit of the detection for $\mathrm{Cd}, \mathrm{Co}, \mathrm{Ni}, \mathrm{V}$. In all samples, $\mathrm{Cd}$ and $\mathrm{Pb}$ are well below the maximum permitted levels in foodstuffs. It can be concluded that the edible flowers analyzed can be considered a good source of essential elements and do not present risks for the consumer health as for the mineral composition.
\end{abstract}

Keywords: essential elements; ICP OES; metals; mineral composition; toxic elements

\section{Introduction}

The term "edible flowers" includes a large number of floral species and varieties which have been used for centuries in many parts of the world, both as ingredients of food recipes and as a decoration, especially for "celebrative" preparations. Although edible flowers can be still considered as a niche market, recently they have become increasingly popular [1,2], because adding flowers to dishes can be a good way to enrich taste, flavor, texture and visual aspect of food [3,4]. Depending on the species, the whole flowers, especially the small ones, or only some parts, in the case of medium and large flowers, are consumed in various ways, namely fresh, dried, candied, or differently cooked. They are mainly used in salads, teas, jams, as a garnish mostly for desserts or cocktails, but creative use has no limits, considering the variety of their sensory properties, including shape and color.

A high number of species of edible flowers, around 180 according to Lu et al. [5], are known worldwide. Some of them can be considered as widely consumed vegetables: it is the case of artichokes, zucchini flowers, cauliflowers and saffron. Others are less common as the presence of some species is 
restricted to certain geo-climatic areas (e.g., hibiscus, mint, sage, pansy, basil), therefore their use is typical of regional cuisines.

From a nutritional point of view, edible flowers are very low in fat and rich in nutrients such as proteins, minerals, vitamins, and bioactive compounds, as flavonoids, carotenoids and anthocyanins that determine their color [1,4-6]. Most of the studies dedicated to edible flowers are focused on nutritional aspects and on health benefits, especially related to antioxidant and antimicrobial activities [7,8], while a few papers deal with the content of trace elements [9-13], despite their relevance for human health.

The presence of trace elements in plants may be related to several factors, such as soil composition, watering and atmospheric pollution, and is strongly depending on the plant species. However, the plant parts usually investigated are roots and leaves, very rarely flowers. Actually, hundreds of plants are known as metal hyper-accumulators [14,15], being able to tolerate one or more trace elements $[16,17]$ even at high levels, concentrating them in their tissues without relevant toxic effects. It has also been hypothesized that hyperaccumulation might play a role as a defensive strategy, contributing to protect plants from pathogens, insects and herbivores [18-20]. Besides elements whose toxicity is well-known, such as cadmium and lead, the concentrations of several micronutrients (e.g., cobalt, copper, iron, manganese, nickel, zinc), which are necessary for plant growth and development, have to be measured. In fact, these elements, although essential also for human health, may be toxic or may induce allergic reactions when beyond certain values $[13,21]$.

The aim of the present work is to provide a further insight into the chemical composition of edible flowers for a more complete definition of the nutritional profile and safety of use. The concentrations of 10 trace elements $(\mathrm{Cd}, \mathrm{Co}, \mathrm{Cu}, \mathrm{Fe}, \mathrm{Mn}, \mathrm{Ni}, \mathrm{Pb}, \mathrm{Sr}, \mathrm{V}$, and $\mathrm{Zn}$ ) were determined by Inductively Coupled Plasma Optical Emission Spectrometry (ICP-OES) in samples of edible flowers from the Ligurian Riviera (North-Western Italy) belonging to 29 species, a wide choice including not only those traditionally used in cooking, but also species mainly known as ornamentals and only recently employed as food. For each species an extensive study of the main botanical characteristics was also performed. The measured concentrations were compared with literature data, although the data available are still scarce and referred to a limited number of floral species and of chemical elements.

\section{Results}

The floral species analyzed are listed in Table $\mathrm{S} 1$ together with their main botanical characteristics and the related references therein [7,22-91]. Table 1 reports the concentrations of the 10 trace elements, expressed as $\mu \mathrm{g} / \mathrm{g}$ dry weight: for each element in each floral species, means and standard deviations were computed after analysis of a number from 2 to 6 of composite samples, obtained as described in Section 4.2.

In most cases, low concentrations were measured; in particular, $68 \%$ of the measurements were below the detection limit for $\mathrm{Cd}(0.020 \mu \mathrm{g} / \mathrm{g}$ dry weight $), 26 \%$ for $\mathrm{Co}(0.030 \mu \mathrm{g} / \mathrm{g}$ dry weight $), 19 \%$ for $\mathrm{V}$ $(0.020 \mu \mathrm{g} / \mathrm{g}$ dry weight), and $10 \%$ for $\mathrm{Ni}(0.070 \mu \mathrm{g} / \mathrm{g}$ dry weight).

Principal component analysis [92] was used as an unsupervised pattern recognition method, allowing to extract and visualize the information contained in the data set (i.e., grouping of samples, presence of outliers, correlated variables, relationships between samples and variables): the first two Components retained the $51 \%$ of the total variance, and $75 \%$ was explained by the first four. Varimax rotation of loadings was performed in order to obtain an easier interpretation of the results. Figure 1a reports the biplot of samples and variables on the plane of the first two varivectors. Most of the samples were grouped at similar, low element concentrations; only the flowers of basil (Ocimum basilicum) and of pumpkins (Cucurbita moschata and C. pepo) showed high concentrations of $\mathrm{Cu}$ and $\mathrm{Sr}$ on varivector 1 (3 times the mean value for the other species), while the flowers of Acmella oleracea were well separated on varivector 2 at high content of $\mathrm{Mn}$ (more than 10 times the mean value for the other species). 
Table 1. Concentrations (expressed as $\mu \mathrm{g} / \mathrm{g}$ dry weight) of 10 trace elements in edible flowers belonging to 29 species. Data are reported as mean value \pm standard deviation. Summary statistics (mean \pm standard deviation, median and range) referred to the whole data set are also shown.

\begin{tabular}{|c|c|c|c|c|c|c|c|c|c|c|}
\hline Species & $\mathrm{Cd}$ & Co & $\mathrm{Cu}$ & $\mathrm{Fe}$ & Mn & $\mathrm{Ni}$ & $\mathbf{P b}$ & $\mathrm{Sr}$ & $\mathrm{V}$ & Zn \\
\hline & \multicolumn{10}{|c|}{ ( $\mu \mathrm{g} / \mathrm{g}$ Dry Weight) } \\
\hline Acmella oleracea (L.) R.K.Jansen & $0.036 \pm 0.014$ & $0.214 \pm 0.149$ & $6.17 \pm 0.40$ & $122.5 \pm 38.0$ & $307.4 \pm 169.9$ & $0.60 \pm 0.15$ & $0.19 \pm 0.13$ & $15.94 \pm 1.22$ & $0.119 \pm 0.037$ & $38.4 \pm 7.7$ \\
\hline Agastache aurantiaca (A.Gray) Lint \& Epling & $<\mathrm{DL}$ & $0.074 \pm 0.002$ & $1.72 \pm 0.44$ & $13.5 \pm 0.7$ & $9.1 \pm 0.4$ & $0.26 \pm 0.05$ & $0.23 \pm 0.16$ & $6.97 \pm 0.90$ & $0.024 \pm 0.003$ & $10.7 \pm 1.9$ \\
\hline Ageratum houstonianum Mill. & $0.210 \pm 0.005$ & $0.148 \pm 0.009$ & $4.34 \pm 0.41$ & $72.5 \pm 0.2$ & $44.1 \pm 1.0$ & $0.41 \pm 0.06$ & $0.32 \pm 0.17$ & $27.35 \pm 0.89$ & $0.079 \pm 0.047$ & $34.2 \pm 2.0$ \\
\hline Antirrhinum majus L. & $<\mathrm{DL}$ & $0.036 \pm 0.006$ & $3.55 \pm 0.21$ & $33.9 \pm 6.2$ & $32.2 \pm 0.9$ & $0.34 \pm 0.30$ & $0.28 \pm 0.07$ & $5.83 \pm 1.13$ & $0.048 \pm 0.039$ & $22.6 \pm 1.6$ \\
\hline Begonia cucullata var. cucullata & $<\mathrm{DL}$ & $0.251 \pm 0.050$ & $7.40 \pm 0.58$ & $67.4 \pm 1.9$ & $59.6 \pm 3.8$ & $1.37 \pm 0.13$ & $0.41 \pm 0.29$ & $28.91 \pm 1.40$ & $0.066 \pm 0.024$ & $34.7 \pm 3.1$ \\
\hline Cucurbita moschata Duchesne & $<$ DL & $0.143 \pm 0.003$ & $18.10 \pm 0.21$ & $115.9 \pm 5.1$ & $25.7 \pm 0.3$ & $1.51 \pm 0.17$ & $0.28 \pm 0.07$ & $37.89 \pm 0.46$ & $0.176 \pm 0.001$ & $63.6 \pm 0.1$ \\
\hline Cucurbita pepo L. & $<\mathrm{DL}$ & $0.079 \pm 0.014$ & $19.61 \pm 3.32$ & $59.9 \pm 6.4$ & $16.3 \pm 8.9$ & $0.50 \pm 0.09$ & $0.29 \pm 0.14$ & $73.84 \pm 25.47$ & $0.100 \pm 0.085$ & $69.6 \pm 4.1$ \\
\hline Dahlia pinnata Cav. & $0.225 \pm 0.009$ & $0.082 \pm 0.017$ & $7.73 \pm 0.48$ & $130.0 \pm 8.2$ & $83.9 \pm 4.7$ & $0.42 \pm 0.10$ & $0.22 \pm 0.11$ & $26.78 \pm 1.67$ & $0.048 \pm 0.016$ & $46.9 \pm 5.3$ \\
\hline Dianthus chinensis L. & $0.068 \pm 0.006$ & $0.421 \pm 0.008$ & $6.17 \pm 0.51$ & $54.6 \pm 2.3$ & $33.3 \pm 2.1$ & $0.38 \pm 0.07$ & $0.06 \pm 0.07$ & $13.49 \pm 1.47$ & $0.040 \pm 0.026$ & $54.7 \pm 2.3$ \\
\hline Fuchsia regia (Vand. ex Vell.) Munz & $<\mathrm{DL}$ & $<\mathrm{DL}$ & $5.21 \pm 0.18$ & $34.2 \pm 2.1$ & $11.3 \pm 0.4$ & $0.26 \pm 0.17$ & $0.17 \pm 0.15$ & $28.50 \pm 1.80$ & $0.074 \pm 0.058$ & $22.6 \pm 0.5$ \\
\hline Hemerocallis fulva (Linn.) Linn. & $<$ DL & $<\mathrm{DL}$ & $5.11 \pm 0.57$ & $18.8 \pm 2.6$ & $13.1 \pm 0.6$ & $3.61 \pm 0.53$ & $0.25 \pm 0.18$ & $5.66 \pm 0.69$ & $0.042 \pm 0.025$ & $30.3 \pm 1.9$ \\
\hline Hibiscus sabdariffa Linn. & $79 \pm 0.004$ & $<\mathrm{DL}$ & $5.88 \pm 0.09$ & $14.0 \pm 0.7$ & $8.1 \pm 0.1$ & $0.82 \pm 0.01$ & $0.28 \pm 0.03$ & $21.42 \pm 0.11$ & $0.045 \pm 0.027$ & $25.8 \pm 0.2$ \\
\hline Monarda didyma $\mathrm{L}$. & $<\mathrm{DL}$ & $<\mathrm{DL}$ & $2.61 \pm 0.20$ & $10.5 \pm 1.2$ & $2.9 \pm 0.2$ & $0.37 \pm 0.02$ & $0.35 \pm 0.35$ & $6.85 \pm 0.75$ & $0.041 \pm 0.027$ & $9.0 \pm 2.0$ \\
\hline $\begin{array}{c}\text { Nepeta } \times \text { faassenii Bergmans } \\
\text { ex Stearn }\end{array}$ & $<\mathrm{DL}$ & $0.116 \pm 0.008$ & $9.92 \pm 0.75$ & $47.5 \pm 1.0$ & $39.8 \pm 0.5$ & $0.81 \pm 0.61$ & $0.28 \pm 0.10$ & $42.91 \pm 0.62$ & $0.049 \pm 0.007$ & $45.1 \pm 1.5$ \\
\hline Ocimum x africanum Lour. & $<\mathrm{DL}$ & $0.110 \pm 0.005$ & $2.22 \pm 0.10$ & $50.9 \pm 0.9$ & $38.9 \pm 0.1$ & $0.22 \pm 0.21$ & $0.26 \pm 0.01$ & $16.35 \pm 0.05$ & $0.050 \pm 0.015$ & $40.0 \pm 4.9$ \\
\hline Ocimum basilicum L. & $<$ DL & $0.442 \pm 0.100$ & $16.62 \pm 1.25$ & $63.2 \pm 7.9$ & $23.3 \pm 2.6$ & $0.39 \pm 0.08$ & $0.30 \pm 0.15$ & $53.00 \pm 4.81$ & $0.065 \pm 0.040$ & $58.5 \pm 1.8$ \\
\hline Salvia discolor Kunth & $<\mathrm{DL}$ & $0.031 \pm 0.001$ & $2.35 \pm 0.37$ & $12.0 \pm 0.3$ & $5.5 \pm 1.6$ & $0.34 \pm 0.20$ & $0.28 \pm 0.06$ & $3.32 \pm 0.08$ & $0.046 \pm 0.035$ & $10.7 \pm 0.2$ \\
\hline Salvia elegans Vahl & $<\mathrm{DL}$ & $0.085 \pm 0.002$ & $9.62 \pm 0.49$ & $20.5 \pm 1.1$ & $8.6 \pm 0.2$ & $0.58 \pm 0.01$ & $0.33 \pm 0.14$ & $8.87 \pm 0.00$ & $0.050 \pm 0.006$ & $19.5 \pm 0.1$ \\
\hline Salvia farinacea Benth. & $0.035 \pm 0.005$ & $0.145 \pm 0.013$ & $5.83 \pm 0.30$ & $39.1 \pm 0.7$ & $24.5 \pm 0.8$ & $0.46 \pm 0.10$ & $0.37 \pm 0.04$ & $20.39 \pm 0.05$ & $0.040 \pm 0.032$ & $50.0 \pm 0.1$ \\
\hline Salvia greggii A.Gray & $<\mathrm{DL}$ & $0.180 \pm 0.020$ & $9.14 \pm 0.23$ & $31.0 \pm 0.3$ & $14.1 \pm 0.6$ & $0.36 \pm 0.22$ & $0.43 \pm 0.04$ & $7.36 \pm 0.08$ & $0.040 \pm 0.006$ & $28.3 \pm 0.4$ \\
\hline Salvia microphylla Kunth & $<$ DL & $0.122 \pm 0.004$ & $5.00 \pm 0.36$ & $15.5 \pm 1.0$ & $23.9 \pm 0.9$ & $0.19 \pm 0.16$ & $0.19 \pm 0.02$ & $4.00 \pm 0.06$ & $0.036 \pm 0.022$ & $24.2 \pm 0.2$ \\
\hline Salvia splendens Sellow ex Nees & $0.105 \pm 0.009$ & $0.105 \pm 0.004$ & $7.54 \pm 0.49$ & $29.7 \pm 6.9$ & $17.0 \pm 0.7$ & $1.09 \pm 0.29$ & $0.89 \pm 1.12$ & $13.35 \pm 0.67$ & $0.051 \pm 0.043$ & $26.8 \pm 2.3$ \\
\hline Salvia $x$ jamensis J. Compton & $<\mathrm{DL}$ & $0.203 \pm 0.014$ & $4.75 \pm 0.07$ & $14.4 \pm 0.70$ & $8.9 \pm 0.2$ & $0.34 \pm 0.05$ & $0.23 \pm 0.07$ & $3.51 \pm 0.07$ & $0.050 \pm 0.024$ & $19.8 \pm 0.8$ \\
\hline Tagetes erecta $\mathrm{L}$. & $0.076 \pm 0.004$ & $0.275 \pm 0.020$ & $4.70 \pm 0.14$ & $42.3 \pm 1.1$ & $86.9 \pm 0.7$ & $0.13 \pm 0.06$ & $0.28 \pm 0.05$ & $10.36 \pm 1.03$ & $0.028 \pm 0.011$ & $25.6 \pm 0.9$ \\
\hline Tagetes lemmonii A. Gray & $0.027 \pm 0.001$ & $0.210 \pm 0.009$ & $9.57 \pm 0.03$ & $54.0 \pm 3.1$ & $24.3 \pm 0.4$ & $1.37 \pm 0.02$ & $0.20 \pm 0.01$ & $28.25 \pm 0.09$ & $0.059 \pm 0.003$ & $38.0 \pm 1.3$ \\
\hline Tulbaghia cominsii Vosa & $0.112 \pm 0.030$ & $<\mathrm{DL}$ & $9.16 \pm 0.05$ & $26.5 \pm 1.4$ & $24.4 \pm 0.6$ & $0.60 \pm 0.04$ & $0.17 \pm 0.16$ & $1.53 \pm 0.07$ & $0.021 \pm 0.001$ & $62.3 \pm 1.1$ \\
\hline Tulbaghia violacea Harv. & $0.038 \pm 0.005$ & $<$ DL & $8.49 \pm 0.17$ & $27.7 \pm 0.5$ & $16.2 \pm 0.2$ & $1.15 \pm 0.13$ & $0.29 \pm 0.05$ & $2.96 \pm 0.20$ & $0.040 \pm 0.028$ & $44.0 \pm 0.9$ \\
\hline Verbena bonariensis L. & $<\mathrm{DL}$ & $<$ DL & $7.62 \pm 0.34$ & $19.9 \pm 0.3$ & $7.7 \pm 0.0$ & $0.38 \pm 0.17$ & $0.46 \pm 0.10$ & $17.69 \pm 0.09$ & $0.025 \pm 0.006$ & $23.2 \pm 1.0$ \\
\hline Viola odorata $L$ & $0.212 \pm 0.004$ & $0.041 \pm 0.004$ & $7.06 \pm 0.13$ & $64.0 \pm 0.3$ & $51.9 \pm 0.0$ & $0.52 \pm 0.00$ & $0.49 \pm 0.01$ & $6.58 \pm 0.13$ & $0.108 \pm 0.019$ & $64.1 \pm 1.6$ \\
\hline Mean \pm standard deviation & $0.102 \pm 0.074$ & $0.160 \pm 0.111$ & $7.35 \pm 4.40$ & $45.0 \pm 32.7$ & $36.7 \pm 56.3$ & $0.68 \pm 0.68$ & $0.30 \pm 0.15$ & $18.62 \pm 16.87$ & $0.057 \pm 0.033$ & $36.0 \pm 17.2$ \\
\hline Median & 0.078 & 0.133 & 6.17 & 34.2 & 23.9 & 0.42 & 0.28 & 13.49 & 0.048 & 34.2 \\
\hline Range (min-max) & $<$ DL-0.225 & $<$ DL-0.442 & $1.72-19.61$ & $10.5-130$ & 2.9-307.4 & $0.13-3.61$ & $0.06-0.89$ & $1.53-73.84$ & $0.021-0.176$ & $9.0-69.6$ \\
\hline
\end{tabular}

$<\mathrm{DL}=$ below detection limit $(0.020 \mu \mathrm{g} / \mathrm{g}$ for $\mathrm{Cd} ; 0.030 \mu \mathrm{g} / \mathrm{g}$ for $\mathrm{Co} ; 0.07 \mu \mathrm{g} / \mathrm{g}$ for Ni; $0.020 \mu \mathrm{g} / \mathrm{g}$ for $\mathrm{V})$. 
In Figure $1 \mathrm{~b}$ the biplot of varivectors 3 and 4 showed as different from the majority of the samples the flowers of scarlet sage (Salvia splendens, 3 times the mean $\mathrm{Pb}$ concentration), flossflower, dahlia and violet (Ageratum houstonianum, Dahlia pinnata and Viola odorata, 3 times the mean Cd concentration), dianthus and basil (Dianthus chinensis and O. basilicum, 4 times the mean Co concentration), separated on varivector 3: the flowers of orange daylily (Hemerocallis fulva, 6 times the mean Ni concentration) were separated on varivector 4 .

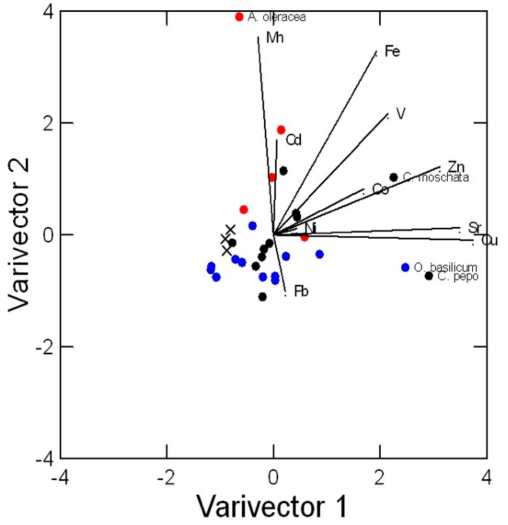

(a)

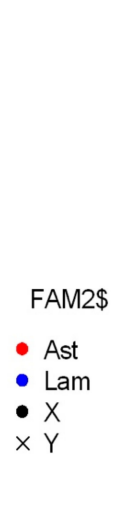

Ast

$X$

$Y$

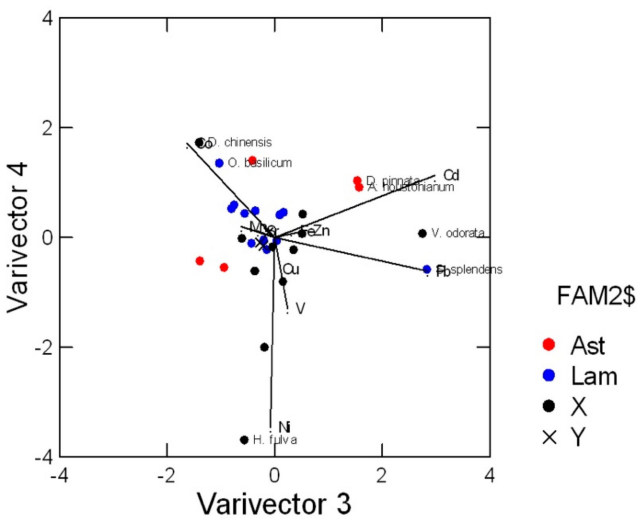

(b)

Figure 1. Results of Principal Component Analysis after Varimax rotation, performed on the data matrix of 29 floral species belonging to different botanical families ( $\bullet$ Asteraceae; $\bullet$ Lamiaceae; $\bullet$ other) described by 10 trace elements. The x symbols indicate snapdragon flowers (Anthirrinum majus) of different colors. Only the names of species at the highest element concentrations are reported. (a) Biplot of varivectors 1 and 2; (b) Biplot of varivectors 3 and 4.

Significant correlations between $\mathrm{Cu}$ and Sr concentrations $(r=0.741, p=0.000)$ and between Fe and V $(r=0.688, p=0.000)$ were found.

In the case of snapdragon flowers (Antirrhinum majus) samples of white, yellow and orange petals were analyzed separately, considering that color may be a relevant factor influencing not only the consumer acceptability of edible flowers but also their chemical composition. As shown in Figure 1, the concentrations of trace elements in the three samples were similar, thus the mean values were used in Table 1.

Moreover, the differences among botanical families were investigated, although this study was possible only for Asteraceae and Lamiaceae, being the only families represented by more than two species (respectively, 5 and 12). As shown in Figure 1a, the flowers of Asteraceae were characterized by higher concentrations of $\mathrm{Cd}$, Fe and $\mathrm{Mn}$ : these differences were found significant on the basis of Mann-Whitney test $(p<0.01)$.

\section{Discussion}

Considering that the flowers of the present study were organically grown in the same place, following the same agricultural practice, the differences detected in their mineral composition can be related to the species. Anyway, even when higher contents of certain trace elements were measured, as highlighted by PCA, the concentrations were far lower than those present in hyperaccumulator species.

Unlike the bioactive compounds responsible for antioxidant activities (flavonoids, xanthophylls and carotenoids), which content is related to petal colours [93], no difference was found among the concentrations of trace elements in flowers of different colors belonging to the same species.

Several Authors highlighted the lack of chemical and toxicological data regarding edible flowers, both spontaneous and cultivated [4,21]. The large number of data here collected contributes to increasing the knowledge in a domain scarcely explored in literature. In fact, the studies regarding 
trace elements in plants are mainly focused on edible and medicinal herbs, either wild or cultivated, on grasses used as pastures or plants used as bioindicators of metal pollution or bioremediation agents, thus the plant parts investigated are in most cases leaves and roots [94-98], while flowers are very rarely studied.

Moreover, the selection of edible flowers may strongly differ from country to country. At our knowledge, no data regarding trace elements are available in literature for many of the species here analyzed. For instance, this is the case of the flowers of A. houstonianum having high concentrations of $\mathrm{Cd}$ and other elements (Table 1): these data are interesting, considering that this plant had shown a remarkable ability to accumulate trace elements from the soil and to translocate them from roots to shoots, being a good candidate for the phytoremediation of soil contaminated by metals, especially $\mathrm{Pb}$, in a study performed in a mine area in Vietnam [99]. In our study, high concentrations of several elements, in particular $\mathrm{Cd}, \mathrm{Co}, \mathrm{Mn}, \mathrm{Ni}$, and $\mathrm{Pb}$, were measured in the flowers of Begonia cucullata var. cucullata, Tagetes erecta and S. splendens: it has to be noted that Ding and $\mathrm{Hu}$ [100], in their study on the potential of ornamental plants as bioindicators in urban environments, had recommended these three species on the basis of the levels of metals in leaves and roots. The higher concentrations of $\mathrm{Co}, \mathrm{Cu}, \mathrm{Sr}$ and $\mathrm{Zn}$ observed in the flowers of $\mathrm{O}$. basilicum can be related to the capacity of accumulating several metals in the shoot and roots of plants grown in natural and contaminated soils [101]. Regarding the flowers of Cucurbitaceae (C. pepo and C. moschata), no data about high concentrations of $\mathrm{Cu}$ and $\mathrm{Sr}$ were found in the literature, although the seeds were reported to be rich in minerals (among the others, $\mathrm{Cu}, \mathrm{Fe}, \mathrm{Sr}, \mathrm{Zn})[102,103]$. Considering that pumpkin flowers are widely consumed, their mineral profile is an added value: moreover, Sotelo et al. [104] reported a high protein content and no antinutritional factors in this floral species.

As for the safety of edible flowers, presently only a few of them (and none of the species of this study) appear on official lists, such as the Novel Food Catalogue [105].

The European Union sets maximum levels for $\mathrm{Cd}$ and $\mathrm{Pb}$ in foodstuffs; assuming that the chemical composition of edible flowers is not too different from other plant organs [1], it is possible to refer to leaf vegetables, where the maximum levels are $0.20 \mathrm{mg} / \mathrm{kg}$ fresh weight for Cd [106] and $0.30 \mathrm{mg} / \mathrm{kg}$ fresh weight for $\mathrm{Pb}$ [107]. None of the samples showed concentrations beyond these limits. The maximum $\mathrm{Cd}$ concentration measured in D. pinnata was $0.04 \mathrm{mg} / \mathrm{kg}$ fresh weight and the maximum Pb concentration measured in S. splendens was $0.16 \mathrm{mg} / \mathrm{Kg}$ fresh weight. Moreover, the mean concentrations were much lower.

Regarding the other elements, data are not sufficient to derive a tolerable upper intake level [108], i.e., a maximum level of total chronic intake judged to be unlikely to pose a risk of adverse health effects in humans. Only for $\mathrm{Cu}$ (from $1 \mathrm{mg} /$ day for children to $5 \mathrm{mg} /$ day for adults) and for $\mathrm{Zn}$ (from 7 to $25 \mathrm{mg} /$ day) this level has been indicated [109], but the small amount of flowers consumed does not pose health risks. Analogously, since an acceptable Mn intake with diet is estimated in the range 1-10 mg/day [109], the use of the spicy flowers of A. oleracea in some recipes cannot cause a relevant intake of this metal. The mean dietary intake of $\mathrm{V}$ is about of 10-20 $\mu \mathrm{g} /$ person/day, but again this value cannot be exceeded when edible flowers are included in diet. Finally, eating food containing Ni can be responsible for dermal reactions [109] in sensitized individuals, but the edible flowers give a scarce contribution to the dietary intake of this metal.

An extensive comparison between our data and the available literature data was performed (Table 2). All of the cited papers reported data of $\mathrm{Cu}, \mathrm{Fe}, \mathrm{Mn}, \mathrm{Zn}$, while the determination of $\mathrm{Cd}, \mathrm{Co}$, $\mathrm{Ni}, \mathrm{Pb}$, and $\mathrm{Sr}$ was perfomed only in some studies, and no data at all were available for $\mathrm{V}$. In addition, the published studies generally include a small number of floral species. Anyway, the values collected in Table 2 show that the concentrations measured in the present study are generally in agreement with literature data, and in many cases are lower than those reported in other studies, although the comparison is made difficult by the enormous variety of geographical origins (Spain, Portugal, Poland, Czech Republic, Russia, Mali, Burkina Faso) and types of samples (from controlled cultivations or from local markets, from clean or polluted areas). 
Table 2. Comparison between the trace element concentrations (average values, as $\mu \mathrm{g} / \mathrm{g}$ dry weight) reported in literature and the data of the present study for the same (or similar) floral species. The concentrations expressed on fresh weight basis in the cited literature were converted to dry weight basis (italic).

\begin{tabular}{|c|c|c|c|c|c|c|c|c|c|c|}
\hline Species & Ref. & $\mathrm{Cd}$ & Co & $\mathrm{Cu}$ & $\mathrm{Fe}$ & Mn & $\mathrm{Ni}$ & $\mathbf{P b}$ & $\mathrm{Sr}$ & $\mathrm{Zn}$ \\
\hline & & & \multicolumn{8}{|c|}{ ( $\mu \mathrm{g} / \mathrm{g}$ Dry Weight) } \\
\hline \multirow{2}{*}{ Acmella oleracea (L.) R.K.Jansen } & [110] & ND & ND & 17.1 & 300 & 107.7 & 3.6 & 3.5 & & 62.8 \\
\hline & Present study & 0.036 & 0.214 & 6.17 & 122.5 & 307.4 & 0.60 & 0.19 & 15.94 & 38.4 \\
\hline \multirow{4}{*}{ Antirrhinum majus L. } & [9] & & & 12.86 & 34.76 & 45.48 & & & & 70.56 \\
\hline & [12] & 0.491 & 0.997 & 4.10 & 75.52 & 9.90 & 1.282 & 1.085 & & 13.23 \\
\hline & [10] & & & 1.97 & 33.8 & 33.8 & 0.18 & & 42.5 & 25.2 \\
\hline & Present study & $<\mathrm{DL}$ & 0.036 & 3.55 & 33.9 & 32.2 & 0.34 & 0.28 & 5.83 & 22.6 \\
\hline Begonia boliviensis & [9] & & & 13.66 & 18.66 & 30.63 & & & & 32.39 \\
\hline Begonia cucullata var. cucullata & Present study & $<\mathrm{DL}$ & 0.251 & 7.40 & 67.4 & 59.6 & 1.37 & 0.41 & 28.91 & 34.7 \\
\hline \multirow{2}{*}{ Dianthus chinensis L. } & [12] & 0.621 & 1.626 & 6.36 & 82.57 & 18.76 & 0.805 & 1.431 & \multirow[b]{2}{*}{13.49} & 31.62 \\
\hline & Present study & 0.068 & 0.421 & 6.17 & 54.6 & 33.3 & 0.38 & 0.06 & & 54.7 \\
\hline Fuchsia $x$ hybrida & [9] & & & 32.14 & 96.67 & 49.64 & & & & 136.31 \\
\hline Fuchsia regia (Vand. ex Vell.) Munz & Present study & $<\mathrm{DL}$ & $<\mathrm{DL}$ & 5.21 & 34.2 & 11.3 & 0.26 & 0.17 & 28.50 & 22.6 \\
\hline Hemerocallis minor & [111] & & & 7.8 & 190 & 22.0 & 3.2 & & 42.0 & 41.3 \\
\hline Hemerocallis $x$ hybrida & [12] & 0.506 & 0.956 & 6.61 & 37.90 & 10.01 & 5.048 & 1.491 & & 28.26 \\
\hline Hemerocallis fulva (Linn.) Linn. & Present study & $<\mathrm{DL}$ & $<\mathrm{DL}$ & 5.11 & 18.8 & 13.1 & 3.61 & 0.25 & 5.66 & 30.3 \\
\hline \multirow{3}{*}{ Hibiscus sabdariffa Linn. } & [112] & & & ND & 61.4 & 100 & & & \multirow[b]{3}{*}{21.42} & 27.1 \\
\hline & [110] & ND & ND & 5.6 & 400 & 243 & 3.1 & 1.8 & & 37.3 \\
\hline & Present study & 0.079 & $<\mathrm{DL}$ & 5.88 & 14.0 & 8.1 & 0.82 & 0.28 & & 25.8 \\
\hline \multirow{2}{*}{ Monarda didyma $\mathrm{L}$. } & [12] & 0.320 & 0.941 & 13.66 & 165.40 & 21.24 & 1.725 & 0.840 & \multirow[b]{2}{*}{6.85} & 42.76 \\
\hline & Present study & $<\mathrm{DL}$ & $<\mathrm{DL}$ & 2.61 & 10.5 & 2.9 & 0.37 & 0.35 & & 9.0 \\
\hline \multirow{2}{*}{ Salvia elegans Vahl } & [13] & 0.0527 & 0.324 & 16.3 & 213 & 95.3 & 0.524 & 0.274 & \multirow[b]{2}{*}{8.87} & 94.3 \\
\hline & Present study & $<\mathrm{DL}$ & 0.085 & 9.62 & 20.5 & 8.6 & 0.58 & 0.33 & & 19.5 \\
\hline \multirow{3}{*}{ Tagetes erecta L. } & [9] & & & 11.60 & 92.77 & 83.62 & & & \multirow[b]{3}{*}{10.36} & 141.38 \\
\hline & [13] & 0.152 & 0.607 & 29.4 & 246 & 46.8 & 0.596 & 0.666 & & 110 \\
\hline & Present study & 0.076 & 0.275 & 4.70 & 42.3 & 86.9 & 0.13 & 0.28 & & 25.6 \\
\hline Viola $x$ wittrockiana & [9] & & & 1.95 & 7.29 & 7.93 & & & \multirow{3}{*}{65.8} & 11.52 \\
\hline Viola $x$ wittrockiana & [10] & & & 5.60 & 51.7 & 67.7 & 0.86 & & & 72.6 \\
\hline Viola tricolor & [13] & 0.579 & 0.571 & 21.1 & 386 & 67.4 & 0.538 & 0.962 & & 152 \\
\hline Viola odorata L. & Present study & 0.212 & 0.041 & 7.06 & 64.0 & 51.9 & 0.52 & 0.49 & 6.58 & 64.1 \\
\hline
\end{tabular}




\section{Materials and Methods}

\subsection{Plant Materials and Plant Culture}

Plant production varied according to species and/or varieties. A. oleracea, A. houstonianum, A. majus, B. cucullata var. cucullata, C. moschata, C. pepo, D. pinnata, D. chinensis, Hibiscus sabdariffa, O. x africanum, O. basilicum, S. farinacea, the two species of Tagetes (T. erecta and T. lemmonii) and V. odorata were propagated by commercial seed. Agastache aurantiaca, Fuchsia regia, Monarda didyma, Nepeta x faassenii, S. discolor, S. elegans, S. greggii, S. microphylla, S. splendens, S. x jamensis, and Verbena bonariensis were propagated by cutting. M. didyma, Nepeta $x$ faassenii and $V$. bonariensis were derived from plants purchased at L'Erbaio della Gorra plant nursery (Casalborgone, TO, Italy); A. aurantiaca, F. regia were provided by CREAM (Nice, France); sage species and varieties were part of the collection at CREA Institute (Sanremo, IM, Italy). Finally, H. fulva, Tulbaghia cominsii and T. violacea were propagated by division of rhizomes and bulbs, respectively. It must be underlined that the accepetd name for the begonia used in this study is B. cucullata var. cucullata, unless it is sometimes reported as Begonia $\times$ semperflorens-cultorum as described by Krauss [113] (Begonia $x$ semperflorens-cultorum hort.; Begonia Semperflorens-Cultorum Group; Begonia semperflorens-cultiform Hort; Begonia semperflorens-cultorum H.K.Krauss; Begonia $x$ hortensis I.Grafl. \& Zwicky).

The seeds of the different species were sown in seedbeds and, after adequate development, the plants were transplanted in pots such as rooted cuttings. Based on the development of plant roots, the pots were $30 \mathrm{~cm}$ of diameter with $9 \mathrm{~L}$ of volume or $14 \mathrm{~cm}$ of diameter with $0.5 \mathrm{~L}$ of volume. The pots contained peaty substrate and pumice (70\% and $30 \%$, respectively) (Hochmoor Vulcan- Terflor, Capriolo, BS, Italy) with slow release fertilizer (Nitrophoska, Eurochem Agro, Cesano Maderno, MB, Italy). All species were grown at CREA in a greenhouse with anti-insect net, and fertirrigated with nutrient solution (Ferti 3, Planta-Düngemittel, Regenstauf, Germany) every week. The plants were grown organically without the use of pesticides as reported in Najar et al. [114]. Briefly, antagonist insects (Adalia bipunctata, Aphidius colemani, Amblyseius swirskii, Chrysoperla carnea, Phytoseiulus persimilis - Koppert Italia Srl., Bussolengo, VR, Italy) and Bacillus thuringensis subsp. Kurstaki (Serbios Srl, Badia Polesine, RO, Italy) were applied in the greenhouse again aphids, thrips, and caterpillars.

\subsection{Sample Preparation}

Fresh flowers at full maturity stage of all species were collected in the morning, between 8 and 10 a.m.; according to the edible use, either the whole flower or only the petals were weighed, packed in paper bags and frozen at $-80^{\circ} \mathrm{C}$. Then the samples were freeze dried (Super Modulyo, Edwards, UK) and weighed again in order to compute the ratio between fresh and dry weight. The mean water content found was $81 \%$ with data ranging from $74 \%$ to $89 \%$.

After homogenization in $25 \mathrm{~mL}$ Teflon grinding jars with zirconium oxide grinding balls (MM2 Mixer Mill, Retsch, Germany), aliquots of 0.13-0.15 g of each floral species were weighed in $120 \mathrm{~mL}$ PTFA advanced composite vessels (MDS 2000, CEM Corporation, USA) and mineralized using $5 \mathrm{~mL}$ of $65 \%(\mathrm{~m} / \mathrm{m})$ nitric acid ('for trace analysis', Scharlau Chemie SA, Spain) in a microwave digestion system (MDS 2000, CEM Corporation, USA) according to the following program: $280 \mathrm{~W}$ for $5 \mathrm{~min}, 440 \mathrm{~W}$ for $10 \mathrm{~min}$, and $600 \mathrm{~W}$ for $25 \mathrm{~min}$. The solutions, after cooling, were transferred to $25 \mathrm{~mL}$ volumetric flasks, diluted to volume using Type I water $(>18 \mathrm{M} \Omega \mathrm{cm})$ (Puranity TU3+, VWR International bvba, Belgium) and filtered using $0.45 \mu \mathrm{m}$ Nylon filters (VWR International LLC, USA). For each floral species this procedure allowed to obtain a composite sample, where the number of flowers was dependent on their size (a minimum of 5-6 for the largest flowers, e.g., C. pepo). Figure 2 shows two steps of the sample preparation. 


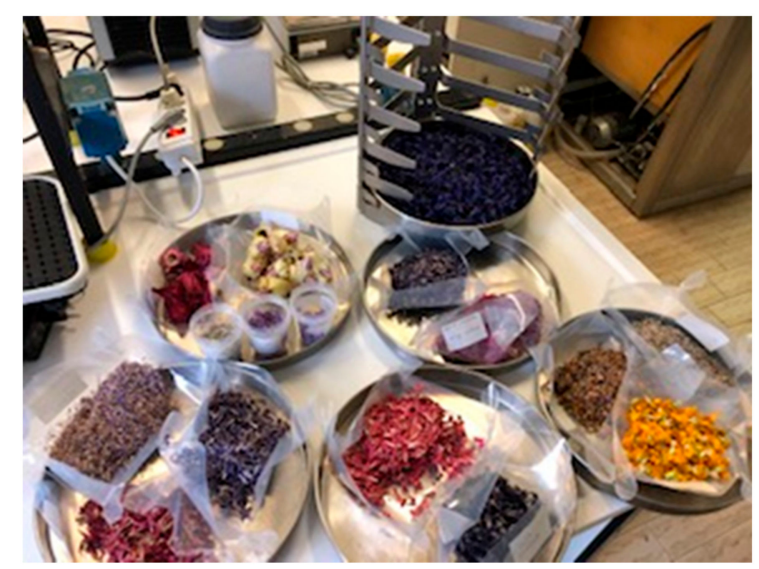

(a)

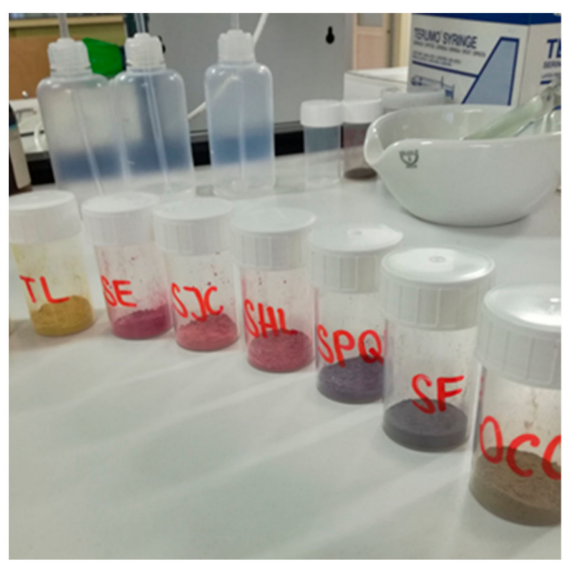

(b)

Figure 2. Two of the steps of sample preparation. (a) Samples after freeze-drying; (b) Samples after homogenization performed in $25 \mathrm{~mL}$ Teflon grinding jars with zirconium oxide grinding balls (MM2 Mixer Mill, Retsch, Germany).

\subsection{Analytical Determinations}

The concentrations of $\mathrm{Cd}, \mathrm{Co}, \mathrm{Cu}, \mathrm{Fe}, \mathrm{Mn}, \mathrm{Ni}, \mathrm{Pb}, \mathrm{Sr}, \mathrm{V}$, and $\mathrm{Zn}$ were measured using atomic emission spectrometry with an inductively coupled plasma source (iCAP 7000 Series, Thermo Scientific, UK). An axial plasma view and a desolvation nebulizer (APEX-E with a MicroFlow PFA-ST concentric nebulizer, Elemental Scientific Inc., USA) were employed to achieve greater sensitivity. The instrument was operated following the indications of the manufacturer. The wavelengths used were selected by means of a built-in library: the selection, performed by the Element Finder plug-in of Qtegra Intelligent Scientific Data Solution (ISDS) software 2.7 (Thermo Scientific, UK) was based on high sensitivity, avoiding interferences with the wavelengths of the other elements, including elements present in the samples and potentially interfering, although not measured (e.g., $\mathrm{Ca}, \mathrm{Mg}, \mathrm{Na}, \mathrm{P}$ ). Plasma was operated at $1150 \mathrm{~W}$ RF power, with a gas (Ar) flow of $12 \mathrm{~L} / \mathrm{min}$ and an auxiliary flow of $0.5 \mathrm{~L} / \mathrm{min}$, with Ar in nebulizer at $0.15 \mathrm{MPa}$.

Calibration was performed with "matrix matching standards" (standard addition method), adding standard solutions in order to match as much as possible the natural concentration of each trace element in the samples to be studied. An addition of $4 \mu \mathrm{g} / \mathrm{mL}$ of $Y$ as internal standard allowed to compensate for matrix difference. All samples were analyzed in duplicate or triplicate and the mean of the results was used. All concentrations were expressed on a dry weight basis. Two blanks were analyzed with each set of samples and subtracted from all measurements. All glassware was washed with $3 \mathrm{M}$ nitric acid and rinsed with Type I water. Wavelengths $(\mathrm{nm})$ and detection limits of the method (based on three times the standard deviation of blanks, as $\mu \mathrm{g} / \mathrm{g}$ dry weight) are reported in Table 3.

Accuracy was assessed by analyzing $(n=7)$ the Standard Reference Material NIST1515 (apple leaves, National Institute of Standards and Technology, NIST). Although NIST1515 is a suitable material (same matrix) for accuracy assessment for most of the trace elements considered, in some cases (Cd and $\mathrm{Co})$ the certified concentrations were below the detection limit of the method or too close to it. For this reason, a second certified material with higher concentrations, BCR 482 (lichen Pseudevernia furfuracea, European Commission, Joint Research Center - Institute for Reference Materials and Measurements, IRMM), was also used $(n=4)$. The results of the quality control, reported in Table 3, were satisfying: in all cases recoveries were between $85 \%$ and $115 \%$ (mean recovery $98 \%$ ). 
Table 3. Quality control performed with the two standard reference materials used, NIST1515 $(n=7)$ and BCR-482 $(n=4)$.For each element the measured concentrations (mean \pm standard deviation) are compared with the certified values (mean \pm half-width of the $95 \%$ confidence interval) or with the reference values (mean \pm standard deviation) indicated in the certification reports. All concentrations are expressed in $\mu \mathrm{g} / \mathrm{g}$ dry weight. Concentration below the detection limit is indicated as $<\mathrm{DL}$. The wavelengths (nm) used in this study and the detection limit (DL) of the method (based on 3 times the standard deviation of blanks, expressed as $\mu \mathrm{g} / \mathrm{g}$ dry weight) are also reported.

\begin{tabular}{ccccccc}
\hline Element & Wavelength & DL & $\begin{array}{c}\text { NIST1515 } \\
\text { Certified }\end{array}$ & $\begin{array}{c}\text { NIST1515 } \\
\text { Measured } \\
(\boldsymbol{7} \text { g/g Dry Weight) }\end{array}$ & $\begin{array}{c}\text { BCR-482 } \\
\text { Certified }\end{array}$ & $\begin{array}{c}\text { BCR-482 } \\
\text { Measured }\end{array}$ \\
\hline $\mathrm{Cd}$ & 226.502 & 0.020 & $0.0132 \pm 0.0015$ & $<\mathrm{LD}$ & $0.56 \pm 0.02$ & $0.584 \pm 0.017$ \\
$\mathrm{Co}$ & 228.616 & 0.030 & $0.09^{1}$ & $0.08 \pm 0.04$ & $0.32 \pm 0.03^{2}$ & $0.287 \pm 0.014$ \\
$\mathrm{Cu}$ & 324.754 & 0.02 & $5.69 \pm 0.13$ & $6.57 \pm 0.22$ & $7.03 \pm 0.19$ & $7.18 \pm 0.28$ \\
$\mathrm{Fe}$ & 259.940 & 0.5 & $82.7 \pm 2.6$ & $70.5 \pm 5.3$ & $804 \pm 160^{2}$ & $692 \pm 78$ \\
$\mathrm{Mn}$ & 257.940 & 0.1 & $54.1 \pm 1.1$ & $58.0 \pm 1.9$ & $33.0 \pm 0.5^{2}$ & $29.3 \pm 1.1$ \\
$\mathrm{Ni}$ & 231.604 & 0.07 & $0.936 \pm 0.094$ & $0.906 \pm 0.074$ & $2.47 \pm 0.07$ & $2.37 \pm 0.46$ \\
$\mathrm{~Pb}$ & 220.353 & 0.02 & $0.47 \pm 0.024$ & $0.57 \pm 0.16$ & $40.9 \pm 1.4$ & $39.7 \pm 2.4$ \\
$\mathrm{Sr}$ & 421.552 & 0.02 & $25.1 \pm 1.1$ & $27.6 \pm 1.1$ & $10.35 \pm 0.24{ }^{2}$ & $8.91 \pm 0.48$ \\
$\mathrm{~V}$ & 311.071 & 0.020 & $0.254 \pm 0.027$ & $0.224 \pm 0.086$ & $3.74 \pm 0.61^{2}$ & $3.43 \pm 0.30$ \\
$\mathrm{Zn}$ & 213.856 & 0.1 & $12.45 \pm 0.43$ & $13.92 \pm 0.94$ & $100.6 \pm 2.2$ & $94.4 \pm 2.4$ \\
\hline
\end{tabular}

${ }^{1}$ Reference value indicated in the certificate of analysis. ${ }^{2}$ Reference values from [115].

\subsection{Data Analysis}

Systat software for Windows Version 13 (Systat Software Inc., USA) was used for statistical analysis and to produce graphs. Principal component analysis (PCA) with Varimax rotation was used for explorative data analysis, as unsupervised pattern recognition technique [91]. The correlations between variables were computed using the Pearson correlation coefficients. Mann-Whitney test, as non-parametric analog of the two-sample t-test, was used for comparing the trace element concentrations in samples belonging to different botanical families. Statistical significance was set at $p$ value $<0.05$.

\section{Conclusions}

The large number of data collected in this study allowed to increase the knowledge in a domain scarcely explored in literature. In fact, the investigation performed covers a wide variety of edible floral species, providing further insights into their health benefits and safety. Moreover, the detailed study of the botanical characteristics of the plant species highlighted their wide geographical diffusion: actually, most of these flowers are consumed in many parts of the world, although they are known under different common names and prepared following a variety of recipes, both traditional and innovative. Regarding the trace elements analyzed, the studied species can be considered a good source of essential elements, without risks for the consumer health. No metal hyperaccumulators were found among the flowers analyzed.

Supplementary Materials: The following are available online at http://www.mdpi.com/1420-3049/25/12/2891/s1, Table S1: Accepted name, family, synonyms, lifeform, geographical distribution, habitat and common names of the selected plant species. Lifeforms are reported according to WCSP (2019). World Checklist of Selected Plant Families. Facilitated by the Royal Botanic Gardens, Kew. Available online: http://apps.kew.org/wcsp/ (accessed on 3 April 2020).

Author Contributions: Conceptualization, G.D. and A.B.; methodology, G.D. and V.M.; validation, G.D. and V.M; formal analysis, V.I.; investigation, G.D. and A.B..; resources, A.C.; data curation, G.D.; writing-original draft preparation, G.D. and A.B.; writing-review and editing, G.D., R.G., V.M., and A.B.; funding acquisition, B.R. and A.B. All authors have read and agreed to the published version of the manuscript. 
Funding: This research was funded by the INTERREG-ALCOTRA UE 2014-2020 Project "ANTEA" Attività innovative per lo sviluppo della filiera transfrontaliera del fiore edule (n. 1139), grant number CUP C12F17000080003. The APC was funded by University of Genova.

Acknowledgments: The authors thank Carlo Mascarello, Sergio Ariano and Alberto Lanteri for the production and cultivation of plant material.

Conflicts of Interest: The authors declare no conflict of interest.

\section{References}

1. Mlcek, J.; Rop, O. Fresh edible flowers of ornamental plants-A new source of nutraceutical foods. Trends Food Sci. Technol. 2011, 22, 561-569. [CrossRef]

2. Fernandes, L.; Casal, S.; Pereira, J.A.; Saraiva, J.A.; Ramalhosa, E. An overview on the market of edible flowers. Food Rev. Int. 2020, 36, 258-275. [CrossRef]

3. Chen, N.H.; Wei, S. Factors influencing consumers' attitudes towards the consumption of edible flowers. Food Qual. Prefer. 2017, 56, 93-100. [CrossRef]

4. Fernandes, L.; Casal, S.; Pereira, J.A.; Saraiva, J.A.; Ramalhosa, E. Edible flowers: A review of the nutritional, antioxidant, antimicrobial properties and effects on human health. J. Food Compos. Anal. 2017, 60, 38-50. [CrossRef]

5. Lu, B.Y.; Li, M.Q.; Yin, R. Phytochemical content, health benefits, and toxicology of common edible flowers: A review (2000-2015). Crit. Rev. Food Sci. 2016, 56, S130-S148. [CrossRef] [PubMed]

6. Chen, G.L.; Chen, S.G.; Xie, Y.Q.; Chen, F.; Zhao, Y.Y.; Luo, C.X.; Gao, Y.Q. Total phenolic, flavonoid and antioxidant activity of 23 edible flowers subjected to in vitro digestion. J. Funct. Foods 2015, 17, 243-259. [CrossRef]

7. Lim, T.K. Edible Medicinal and Non-Medicinal Plants-Volume 7-Flowers; Springer Netherlands: Dordrecht, The Netherlands, 2014; p. 1102. [CrossRef]

8. Lim, T.K. Edible Medicinal and Non-Medicinal Plants_Volume 8-Flowers; Springer Netherlands: Dordrecht, The Netherlands, 2014; p. 1024. [CrossRef]

9. Rop, O.; Mlcek, J.; Jurikova, T.; Neugebauerova, J.; Vabkova, J. Edible flowers-A new promising source of mineral elements in human nutrition. Molecules 2012, 17, 6672-6683. [CrossRef] [PubMed]

10. Gonzalez-Barrio, R.; Periago, M.J.; Luna-Recio, C.; Javier, G.A.F.; Navarro-Gonzalez, I. Chemical composition of the edible flowers, pansy (Viola wittrockiana) and snapdragon (Antirrhinum majus) as new sources of bioactive compounds. Food Chem. 2018, 252, 373-380. [CrossRef]

11. Dos Santos, A.M.P.; Silva, E.F.; dos Santos, W.N.L.; da Silva, E.G.; dos Santos, L.O.; Santos, B.R.D.S.; Sauthier, M.C.D.S.; dos Santos, W.P. Evaluation of minerals, toxic elements and bioactive compounds in rose petals (Rosa spp.) using chemometric tools and artificial neural networks. Microchem. J. 2018, 138, 98-108. [CrossRef]

12. Grzeszczuk, M.; Stefaniak, A.; Meller, E.; Wysocka, G. Mineral composition of some edible flowers. J. Elementol. 2018, 23, 151-162. [CrossRef]

13. Araujo, S.; Matos, C.; Correia, E.; Antunes, M.C. Evaluation of phytochemicals content, antioxidant activity and mineral composition of selected edible flowers. Qual. Assur. Saf. Crop 2019, 11, 471-478. [CrossRef]

14. Kramer, U. Metal hyperaccumulation in plants. Annu. Rev. Plant Biol. 2010, 61, 517-534. [CrossRef] [PubMed]

15. Reeves, R.D.; Baker, A.J.M.; Jaffré, T.; Erskine, P.D.; Echevarria, G.; van der Ent, A. A global database for plants that hyperaccumulate metal and metalloid trace elements. New Phytol. 2018, 218, 407-411. [CrossRef] [PubMed]

16. Van der Ent, A.; Baker, A.J.M.; Reeves, R.D.; Pollard, A.J.; Schat, H. Hyperaccumulators of metal and metalloid trace elements: Facts and fiction. Plant Soil 2013, 362, 319-334. [CrossRef]

17. Reeves, R.D.; Baker, A.J.M. Metal accumulating plants. In Phytoremediation of Toxic Metals: Using Plants to Clean up the Environment; Raskin, I., Finsley, B.D., Eds.; Wiley: New York, NY, USA, 2000; pp. 193-229.

18. Boyd, R.S. The defense hypothesis of elemental hyperaccumulation: Status, challenges and new directions. Plant Soil 2007, 293, 153-176. [CrossRef] 
19. Rascio, N.; Navari-Izzo, F. Heavy metal hyperaccumulating plants: How and why do they do it? And what makes them so interesting? Plant Sci. 2011, 180, 169-181. [CrossRef]

20. Stolpe, C.; Krämer, U.; Müller, C. Heavy metal (hyper)accumulation in leaves of Arabidopsis halleri is accompanied by a reduced performance of herbivores and shifts in leaf glucosinolate and element concentrations. Environ. Exp. Bot. 2017, 133, 78-86. [CrossRef]

21. Mithril, C.; Dragsted, L.O. Safety evaluation of some wild plants in the New Nordic Diet. Food Chem. Toxicol. 2012, 50, 4461-4467. [CrossRef]

22. IPNI. The International Plant Names Index. Royal Botanic Gardens Kew, UK. 2020. Available online: http://www.ipni.org (accessed on 10 June 2020).

23. POWO. Plants of the World Online. Facilitated by the Royal Botanic Gardens, KewRoyal Botanic Gardens: Kew, UK. 2020. Available online: http://www.plantsoftheworldonline.org/ (accessed on 10 June 2020).

24. WCSP. World Checklist of Selected Plant Families; Royal Botanic Gardens: Kew, UK, 2020; Available online: http://apps.kew.org/wcsp/ (accessed on 10 June 2020).

25. Brummitt, R.K. World Geographical Scheme for Recording Plant Distributions; Hunt Institute for Botanical Documentation Carnegie Mellon University: Pittsburgh, PA, USA, 2001; p. 153.

26. Jørgensen, P.M. Bolivia checkliste. Floras.org, eFloras: 2004. Available online: http://www.efloras.org/flora_p age.aspx?flora_id=40 (accessed on 10 June 2020).

27. Flora of North America Editorial Committee. Flora of North America North of Mexico. Oxford University Press: 1993+. Available online: http://beta.floranorthamerica.org/Main_Page (accessed on 10 June 2020).

28. Jansen, R.T. The Systematics of Acmella (Asteraceae-Heliantheae). In Systematic Botany Monographs Volume 8, The Systematics of Acmella (Asteraceae-Heliantheae); American Society of Plant Taxonomists: Laramie, WY, USA, 1985; pp. 1-115.

29. Roskov, Y.; Ower, G.; Orrell, T.; Nicolson, D.; Bailly, N.; Kirk, P.M.; Bourgoin, T.; DeWalt, R.E.; Decock, W.; Nieukerken, E.; et al. Species 2000 E ITIS Catalogue of Life, 2019 Annual Checklist; Species 2000; Naturalis: Leiden, The Netherlands, 2019.

30. PROTA4U. Plant Resources of Tropical Africa; PROTA Network Office Europe, Wageningen University: Wageningen, The Netherlands, 2020; Available online: https://www.prota4u.org/ (accessed on 10 June 2020).

31. Hind, N.; Biggs, N. Acmella oleracea: Compositae. Curtis's Bot. Mag. 2003, 20, 31-39. [CrossRef]

32. GBIF. The Global Biodiversity Information Facility; GBIF Secretariat: Copenhagen, Denmark, 2020; Available online: https://www.gbif.org/ (accessed on 10 June 2020).

33. NPGS. U.S. National Plant Germplasm System. Germplasm Resources Information Network (GRIN-Taxonomy). U.S. Department Of Agriculture-Agricultural Research Service; 2020. Available online: https://npgsweb.ars-grin.gov/gringlobal/taxon/taxonomysearch.aspx (accessed on 10 June 2020).

34. Sanders, R.W. Taxonomy of Agastache Section Brittonastrum (Lamiaceae-Nepeteae). In Systematic Botany Monographs; American Society of Plant Taxonomists: Laramie, WY, USA, 1987; Volume 15, pp. 1-92. Available online: https://www.jstor.org/stable/25027677?origin=JSTOR-pdf\&seq=1\&socuuid=d3afc394-af42-431c-8b 2b-0af0a0a20f8f\&socplat=email\#metadata_info_tab_contents (accessed on 22 June 2020).

35. FNA. Flora of North America. In eFloras.org, Flora of North America Editorial Committee, Oxford University Press: 2020. Available online: http://www.efloras.org/flora_page.aspx?flora_id=1 (accessed on 10 June 2020).

36. Lamsal, A.; Devkota, M.P.; Shrestha, D.S.; Joshi, S.; Shrestha, A. Seed germination ecology of Ageratum houstonianum: A major invasive weed in Nepal. PLoS ONE 2019, 14, e0225430. [CrossRef]

37. Shin, S.Y.; Lee, D.H.; Gil, H.-N.; Kim, B.S.; Choe, J.-S.; Kim, J.-B.; Lee, Y.H.; Lim, Y. Agerarin, identified from Ageratum houstonianum, stimulates circadian CLOCK-mediated aquaporin-3 gene expression in HaCaT keratinocytes. Sci. Rep. 2017, 17, 1-13. [CrossRef] [PubMed]

38. APNI. Vascular Plants Australian Plant Name Index. In National Species List 2020. Available online: https://biodiversity.org.au/nsl/services/apni (accessed on 10 June 2020).

39. PlantNET. The NSW Plant Information Network System; Royal Botanic Gardens and Domain Trust: Sydney, Australia, 2020. Available online: http://plantnet.rbgsyd.nsw.gov.au (accessed on 10 June 2020).

40. CABI. Invasive Species Compendium; CAB International: Wallingford, UK, 2020; Available online: www.cabi.org/isc (accessed on 10 June 2020). 
41. PFAF. Plants for a Future. In Ken Fern/Plants for a Future (1995-2019). 2020. Available online: https: //pfaf.org/user/Default.aspx (accessed on 10 June 2020).

42. Martellos, S.; Nimis, P.L. Portale della Flora d'Italia-Portal to the Flora of Italy 2019.2. 2020. Available online: http:/dryades.units.it/floritaly (accessed on 10 June 2020).

43. Webb, D.A. Antirrhinum L. In Flora Europaea; Tutin, T.G., Heywood, V.H., Burges, N.A., Moore, D.M., Valentine, D.H., Walters, S.M., Webb, D.A., Eds.; Cambridge University Press: Cambridge, UK, 1972; Volume III, p. 221224.

44. Pujol, B.; Archambeau, J.; Bontemps, A.; Lascoste, M.; Marin, S.; Meunier, A. Mountain landscape connectivity and subspecies appurtenance shape genetic differentiation in natural plant populations of the snapdragon (Antirrhinum majus L.). Bot. Lett. 2017, 164, 111-119. [CrossRef]

45. Liljeblad, J. Dyntaxa. Svensk taxonomisk databas. Version 1.2ArtDatabanken. 2020. Available online: https://www.dyntaxa.se/ (accessed on 10 June 2020).

46. Pounders, C.T.; Sakhanokho, H.F.; Nyochembeng, L.M. Begonia $x$ semperflorens FB08-59 and FB08-163 Clonal Germplasm. Hort. Sci. 2015, 50, 145-146. [CrossRef]

47. PIER. US Forest Service, Pacific Island Ecosystems at Risk Institute of Pacific Islands Forestry 2020. Available online: http://www.hear.org/pier/ (accessed on 10 June 2020).

48. GISD. Global Invasive Species Database. Invasive Species Specialist Group (ISSG) of the IUCN Species Survival Commission: 2020. Available online: http://www.iucngisd.org/gisd/ (accessed on 10 June 2020).

49. Salehi, B.; Sharifi-Rad, J.; Capanoglu, E.; Adrar, N.; Catalkaya, G.; Shaheen, S.; Jaffer, M.; Giri, L.; Suyal, R.; Jugran, A.K.; et al. Cucurbita Plants: From Farm to Industry. Appl. Sci. 2019, 9, 3387. [CrossRef]

50. Hidayati, N.R.; Suranto, S.; Sajidan, S. Morphological characteristics and isozyme banding patterns of Cucurbita moschata at different altitudes. Biodiversitas 2018, 19, 1683-1689. [CrossRef]

51. OECD. Squashes, pumpkins, zucchinis and gourds (Curcurbita species). In Safety Assessment of Transgenic Organisms in the Environment; Publishing, O., Ed.; OECD Consensus Documents: Paris, France, 2016; Volume 5, pp. 83-149.

52. Decker, D.S. Origin(s), Evolution, and Systematics of Cucurbita pepo (Cucurbitaceae). Econ. Bot. 1988, 42, 4-15. [CrossRef]

53. Hansen, H.V. Simplified keys to four sections with 34 species in the genus Dahlia (Asteraceae-Coreopsideae). Nord. J. Bot. 2007, 24, 549-553. [CrossRef]

54. Sorensen, P.D. Revision of the Genus Dahlia (Compositae, Heliantheae-Coreopsidinae). Rhodora 1969, 71, 309-416.

55. Saar, D.E.; Polans, N.O.; Sørensen, P.D. A Phylogenetic Analysis of the Genus Dahlia (Asteraceae) Based on Internal and External Transcribed Spacer Regions of Nuclear Ribosomal DNA. Syst. Bot. 2003, 28, 627-639.

56. Carrasco-Ortiz, M.; Munguía-Lino, G.; Castro-Castro, A.; Vargas-Amado, G.; Harker, M.; Rodríguez, A. Riqueza, distribución geográfica y estado de conservación del género Dahlia (Asteraceae) en México. Acta Bot. Mex. 2019, 126, e1354. [CrossRef]

57. Wu, C.-Y.; Ping, K.; Zhou, L-H.; Tang, C.-L.; Lu, D.-Q. Caryophyllaceae. In Flora Reipublicae Popularis Sinicae; Science Press: Beijing, China, 1996; Volume 26, pp. 47-449.

58. Dequan, L.; Zhengyi, W.; Cheng-yih, W.; Li-hua, Z.; Shilong, C.; Gilbert, M.G.; Lidén, M.; McNeill, J.; Morton, J.K.; Oxelman, B.; et al. Caryophyllaceae through Lardizabalaceae. In Flora of China; Wu, Z.Y., Raven, P.H., Hong, D.Y., Eds.; Science Press: Beijing, China; Missouri Botanical Garden Press: St. Louis, MO, USA, 2001; Volume 6, pp. 1-113.

59. Berry, P.E. A Sistematic Revision of Fuchsia Sect. Quelusia (Onagraceae). Ann. Missoury Bot. Gard. 1989, 76, 532-584. [CrossRef]

60. Rodrigues, D.M.; Singer, R.B. As subespécies de Fuchsia regia (Vand. ex Vell.) Munz (Onagraceae) ocorrentes no Rio Grande do Sul, Brasil. Iheringia Ser. Bot. 2014, 69, 257-266.

61. Munz, P.A. A Revision of the Genus Fuchsia (Onagraceae). In Proceedings of the California Academy of Sciences, 4th Series; California Academy of Sciences: San Francisco, CAS, USA, 1943; Volume 25, pp. 1-138.

62. Wilson, F.D. Revision of Hibiscus section Furcaria (Malvaceae) in Africa and Asia. Bull. Nat. Hist. Mus. 1999, $29,47-79$.

63. Craven, L.A.; Wilson, F.D.; Fryxell, P.A. A taxonomic review of Hibiscus sect. Furcaria (Malvaceae) in Western Australia and the Northern Territory. Aust. Syst. Bot. 2003, 16, 185-218. [CrossRef] 
64. Tropicos. Missouri Botanical Garden: 2020. Available online: https://www.tropicos.org/home (accessed on 10 June 2020).

65. Lester, R.K.; Vandevender, J. Plant Guide for scarlet beebalm (Monarda didyma). In USDA-Natural Resources Conservation Service; Appalachian Plant Materials Center: Alderson, WV, USA, 2015; p. 24910.

66. Davidson, C.G. Monarda, Bee-balm. In Flower Breeding and Genetics; Anderson, N.O., Ed.; Springer: Dordrecht, The Netherlands, 2007; pp. 757-779.

67. Whitten, W.M. Pollination Ecology of Monarda didyma, M. clinopodia, and Hybrids (Lamiaceae) in the Southern Appalachian Mountains. Am. J. Bot. 1981, 68, 435-442. [CrossRef]

68. Shasany, A.K.; Kole, C. The Ocimum Genome; Springer Nature Switzerland: Basel, Switzerland, 2018. [CrossRef]

69. Paton, A.; Putievsky, E. Taxonomic problems and cytotaxonomic relationships between and within varieties of Ocimum basilicum and related species (Labiatae). Kew Bull. 1996, 51, 509-524. [CrossRef]

70. Chowdhury, T.; Mandal, A.; Chandra Roy, S.; De Sarker, D. Diversity of the genus Ocimum (Lamiaceae) through morpho-molecular (RAPD) and chemical (GC-MS) analysis. J. Genet. Eng. Biotechnol. 2017, 15, 275-286. [CrossRef]

71. Epling, C. A Revision of Salvia, Subgenus Calosphace; University of California Press-1939 Verlag des Repertoriums, Dahlem dei Berlin: Berkeley, CA, USA, 1940; Volume 110, p. 383.

72. Jenks, A.A.; Walker, J.B.; Kim, S.-C. Phylogeny of New World Salvia subgenus Calosphace (Lamiaceae) based on cpDNA (psbA-trnH) and nrDNA (ITS) sequence data. J. Plant Res. 2013, 126, 483-496. [CrossRef]

73. Epling, C.; Jativa, C. Supplementary notes on American Labiatae VIII. Brittonia 1963, 15, 366-376. [CrossRef]

74. Epling, C. Supplementary notes on American Labiatae. Bull. Torrey Bot. Club 1940, 67, 509-534. [CrossRef]

75. Fernald, M.L. A Synopsis of the Mexican and Central American Species of Salvia. Proceedings of the American Academy; American Academy of Arts and Sciences: Cambridge, MA, USA, 1900; Volume 35. Available online: https://www.jstor.org/stable/25129966?seq=1\#metadata_info_tab_contents (accessed on 22 June 2020).

76. Bentham, G. Labiatarum Genera et Species; Ridgway: London, UK, 1836.

77. Martínez-Gordillo, M.; Bedolla-García, B.; Cornejo-Tenorio, G.; Fragoso-Martínez, I.; García-Peña, M.d.R.; González-Gallegos, J.G.; Lara-Cabrera, S.I.; Zamudio, S. Lamiaceae de México. Bot. Sci. 2017, 95, 780-806. [CrossRef]

78. Fragoso-Martínez, I.; Martínez-Gordillo, M.; Salazar, G.A.; Sazatornil, F.; Jenks, A.A.; Peña, M.d.R.G.; Barrera-Aveleida, G.; Benitez-Vieyra, S.; Magallón, S.; Cornejo-Tenorio, G. Phylogeny of the Neotropical sages (Salvia subg. Calosphace; Lamiaceae) and insights into pollinator and area shifts. Plant Syst. Evol. 2018, 304, 43-55. [CrossRef]

79. Turner, B.L. Recension of Salvia sect. Farinaceae (Lamiaceae). Phytologia 2008, 90, 163-175.

80. Pauwels, L. Observations sur le genre Salvia L. (Lamiaceae) en Afrique tropicale. Bull. Jard. Bot. Nat. Belg. 1987, 57, 261-265. [CrossRef]

81. Saez, L.; Salvia, L. Flora Iberica; Morales, R., Quintanar, A., Cabezas, F., Pujadas, A.J., Cirujano, S., Eds.; Real Jardin Botanico: Madrid, Spain, 2010; Volume 12, pp. 298-326. Available online: http://www.floraiberic a.es/floraiberica/texto/pdfs/12_140_15_Salvia.pdf (accessed on 22 June 2020).

82. Villaseñor, J.L. Checklist of the native vascular plants of Mexico. Rev. Mex. Biodivers. 2016, 87, 559-902. [CrossRef]

83. Hooker, J.D. Curtis's Botanical Magazine; Reeve: London, UK, 1885; Volume 41.

84. Epling, C. Supplementary Notes on American Labiatae-V. Brittonia 1951, 7, 129-142. [CrossRef]

85. Compton, J. Mexican salvias in cultivation. The Plantsman 1994, 15, 193-215.

86. Wood, J.R.I.; Harley, R.M. The genus Salvia (Labiatae) in Colombia. Kew Bull. 1988, 44, 211-278. [CrossRef]

87. The Plant List. The Plant List Version 1.1. 2013. Available online: http://www.theplantlist.org/ (accessed on 10 June 2020).

88. Vosa, G.C. Notes on Tulbaghia: 1. A new speciesfrom the eastern cape and a list of new localities. J. S. Afr. Bot. 1979, 45, 127-132.

89. Vosa, C.G. A revised cytotaxonomy of the genus Tulbaghia (Alliaceae). Caryologia 2000, 53, 83-112. [CrossRef]

90. Acta Plantarum, from 2007 on 2020. Available online: https://www.actaplantarum.org/ (accessed on 10 June 2020).

91. JSTOR. Global Plants. 2020. Available online: https://plants.jstor.org/ (accessed on 10 June 2020). 
92. Jackson, J.E. A User's Guide to Principal Components; John Wiley \& Sons, Inc.: Hoboken, NJ, USA, $2004 ;$ p. 575. [CrossRef]

93. Skowyra, M.; Calvo, M.I.; Gallego, M.G.; Azman, N.A.M.; Almajano, M.P. Characterization of phytochemicals in petals of different colours from Viola $\times$ wittrockiana Gams and their correlation with antioxidant activity. J. Agric. Sci. 2014, 6, 93-105. [CrossRef]

94. Kabata-Pendias, A. Trace Elements in Soil and Plants, 4th ed.; CRC Press: Boca Raton, FL, USA, 2010.

95. Kumar, V.; Sharma, A.; Dhunna, G.; Chawla, A.; Bhardwaj, R.; Thukral, A.K. A tabulated review on distribution of heavy metals in various plants. Environ. Sci. Pollut. Res. 2017, 24, 2210-2260. [CrossRef] [PubMed]

96. Manzoor, J.; Sharma, M.; Wani, K.A. Heavy metals in vegetables and their impact on the nutrient quality of vegetables: A review. J. Plant Nutr. 2018, 41, 1744-1763. [CrossRef]

97. Drava, G.; Cornara, L.; Giordani, P.; Minganti, V. Trace elements in Plantago lanceolata L., a plant used for herbal and food preparations: New data and literature review. Environ. Sci. Pollut. Res. 2019, 26, 2305-2313. [CrossRef] [PubMed]

98. Kumar, S.; Prasad, S.; Yadav, K.K.; Shrivastava, M.; Gupta, N.; Nagar, S.; Bach, Q.V.; Kamyab, H.; Khan, S.A.; Yadav, S.; et al. Hazardous heavy metals contamination of vegetables and food chain: Role of sustainable remediation approaches-A review. Environ. Res. 2019, 179, 108792. [CrossRef] [PubMed]

99. Nguyen, T.H.H.; Sakakibara, M.; Sano, S.; Mai, T.N. Uptake of metals and metalloids by plants growing in a lead-zinc mine area, Northern Vietnam. J. Hazard. Mater. 2011, 186, 1384-1391. [CrossRef] [PubMed]

100. Ding, Z.H.; Hu, X. Transfer of heavy metals (Cd, Pb, $\mathrm{Cu}$ and $\mathrm{Zn}$ ) from roadside soil to ornamental plants in Nanjing, China. Adv. Mater. Res. 2011, 356-360, 3051-3054. [CrossRef]

101. Boechat, C.L.; Carlos, F.S.; Gianello, C.; Camargo, F.A.D. Heavy Metals and Nutrients Uptake by Medicinal Plants Cultivated on Multi-metal Contaminated Soil Samples from an Abandoned Gold Ore Processing Site. Water Air Soil Pollut. 2016, 227. [CrossRef]

102. Mansour, E.H.; Dworschak, E.; Lugasi, A.; Barna, E.; Gergely, A. Nutritive value of pumpkin (Cucurbita pepo Kakai-35) seed products. J. Sci. Food Agric. 1993, 61, 73-78. [CrossRef]

103. European Medicines Agency. Assessment Report on Cucurbita pepo L., semen (EMA/HMPC/136022/2010). Committee on Herbal Medicinal Products: London, UK, 2013; p. 7. Available online: https://www.ema.euro pa.eu/en/documents/herbal-report/draft-assessment-report-cucurbita-pepo-1-semen_en.pdf (accessed on 10 June 2020).

104. Sotelo, A.; Lopez-Garcia, S.; Basurto-Pena, F. Content of nutrient and antinutrient in edible flowers of wild plants in Mexico. Plant Food Hum. Nutr. 2007, 62, 133-138. [CrossRef]

105. EU Novel Food Catalogue. Available online: https://ec.europa.eu/food/safety/novel_food/catalogue/search/p ublic/index.cfm (accessed on 14 May 2020).

106. European Community Commission Regulation (EC) No 488/2014 of 12 May 2014 Amending Regulation (EC) No 1881/2006 as Regards Maximum Levels of Cadmium in Foodstuffs. 2014. Available online: http://eur-lex. europa.eu/legal-content/EN/TXT/PDF/?uri=CELEX:32014R0488\&from=IT (accessed on 10 June 2020).

107. European Community Commission Regulation (EC) No 629/2008 of 2 July 2008 Amending Regulation (EC) No 1881/2006 Setting Maximum Levels for Certain Contaminants in Foodstuffs. 2008. Available online: http://eur-lex.europa.eu/LexUriServ/LexUriServ.do?uri=OJ:L:2008:173:0006:0009:EN:PDF (accessed on 10 June 2020).

108. EFSA. European Food Safety Authority Dietary Reference Values for Nutrients: Summary Report; EFSA Supporting Publication; EFSA: Parma, Italy, 2017; Available online: https://efsa.onlinelibrary.wiley.com/doi/epdf/10.290 3/sp.efsa.2017.e15121 (accessed on 10 June 2020).

109. EFSA. European Food Safety Authority Tolerable Upper Intake Levels for Vitamins and Minerals (No. EMA/HMPC/437859/2010). Available online: http://www.efsa.europa.eu/sites/default/files/efsa_re p/blobserver_assets/ndatolerableuil.pdf (accessed on 10 June 2020).

110. Maiga, A.; Diallo, D.; Bye, R.; Paulsen, B.S. Determination of some toxic and essential metal ions in medicinal and edible plants from Mali. J. Agric. Food Chem. 2005, 53, 2316-2321. [CrossRef] [PubMed]

111. Chuparina, E.V.; Aisueva, T.S. Determination of heavy metal levels in medicinal plant Hemerocallis minor Miller by X-ray fluorescence spectrometry. Environ. Chem. Lett. 2011, 9, 19-23. [CrossRef] 
112. Glew, R.H.; VanderJagt, D.J.; Lockett, C.; Grivetti, L.E.; Smith, G.C.; Pastuszyn, A.; Millson, M. Amino Acid, Fatty Acid, and Mineral Composition of 24 Indigenous Plants of Burkina Faso. J. Food Compos. Anal. 1997, 10, 205-217. [CrossRef]

113. Krauss, H.H. Begonias for American Homes and Gardens; Macmillan: New York, NY, USA, 1947.

114. Najar, B.; Marchioni, I.; Ruffoni, B.; Copetta, A.; Pistelli, L.; Pistelli, L. Volatilomic Analysis of Four Edible Flowers from Agastache Genus. Molecules 2019, 24. [CrossRef] [PubMed]

115. Quevauviller, P.; Herzig, R.; Muntau, H. EUR Report; European Commission: Brussels, Belgium, 1996.

Sample Availability: Samples are available from CREA Centro di ricerca Orticoltura e Florovivaismo, Corso Inglesi 508, 18038 Sanremo, IM, Italy.

(C) 2020 by the authors. Licensee MDPI, Basel, Switzerland. This article is an open access article distributed under the terms and conditions of the Creative Commons Attribution (CC BY) license (http://creativecommons.org/licenses/by/4.0/). 